\title{
Histopathological changes in kidney and pancreas induced by energy drinks in adult male rats
}

\author{
A.H. Qassim ${ }^{\circledR}$, M.A. Al sammak ${ }^{\circledR}$ and A.A. Ayoob ${ }^{\circledR}$ \\ Department of Anatomy, Histology and Embryology, College of Medicine, University of Mosul, Mosul, Iraq
}

\begin{tabular}{l} 
Article information \\
\hline Article history: \\
Received January 29, 2021 \\
Accepted March 21, 2021 \\
Available online November 19, 2021 \\
\hline Keywords: \\
Energy drink \\
Kidney \\
Pancreas \\
Red bull \\
Vascular congestion \\
\hline Correspondence: \\
A.H. Qassim \\
ahmedhq@ uomosul.edu.iq
\end{tabular}

\begin{abstract}
The study aims to assess the impact of various doses of red bull on kidney and pancreas of male albino rats. Thirty male albino rats were assigned to three groups (10 animals/ group). Control group 1 received standard diet and water, group 2 and group 3 received daily oral doses of $10 \mathrm{ml} / \mathrm{kg} / \mathrm{rat}$ and $20 \mathrm{ml} / \mathrm{kg} / \mathrm{rat}$ of the energy drink (red bull) respectively for 30 days. Under light microscope no tissue changes were seen in kidney and pancreas of control group. In group 2 red bull causes vacuolar degeneration as well as coagulative necrosis of renal tubular epithelium, vascular congestion in the glomeruli and in the interstitial space of the kidney, in addition to atrophy of the glomeruli, as regard to pancreas it causes vascular congestion of the islets of Langerhans, increase in the size of the islets, besides, necrosis of Langerhans cells. In group 3 red bull leads to more atrophic glomeruli, massive coagulative necrosis of renal tubular epithelium, marked vascular dilatation and congestion in the interstitial space and degenerative changes of the renal tubular epithelium, whereas the pancreatic tissue revealed reduction in the size of the islets of Langerhans, vacuolation and degeneration of their cells, necrosis of other islets with mononuclear inflammatory cells infiltration and degenerative changes of pancreatic acini. It is concluded that administration of red bull to rats for 30 days will affect the histological structure of kidney as well as pancreas and this effect is a dose dependent.
\end{abstract}

DOI: $10.33899 /$ ijvs.2021.129435.1647, (CAuthors, 2022, College of Veterinary Medicine, University of Mosul.

This is an open access article under the CC BY 4.0 license (http://creativecommons.org/licenses/by/4.0/).

\section{Introduction}

Energy drinks are popular and commonly consumed worldwide particularly by adults aging 35 years and less due to their ability to boast mental and physical performance (1). There are many kinds of energy drinks such as tiger, red bull and power horse, all these beverages mainly contain caffeine, in addition to water, carbohydrates, vitamins, amino acids and minerals (2). Although these ingredients are responsible for the desired effects of energy drinks (like increasing the level of energy, enhancement of physical activity, reduction of mental exhaustion and improvement in the mood), but they can also cause hazardous effects (3).

Consumption of caffeinated energy drink may induce nephrotoxicity (4), hematological disorders (5), hepatitis and pancreatitis (6). Furthermore, the high sugar content results in obesity and diabetes (7), whereas the disturbances in the homeostasis of the non-essential amino acid taurine which is another component of energy drinks may affect brain, heart and even skeletal system of human (8). Recently they found that allergic disorders are associated with energy drink consumption (9). Since the intake of energy drinks became a phenomenon throughout the world and because of their risks to human health, there is an increasing interest for conducting experimental studies, as well as, researches in order to evaluate and understand their impact on different body organs.

One of these studies is the present study which is aimed to assess the impact of different doses of red bull on kidney and pancreas of male albino rats. 


\section{Materials and methods}

\section{Chemicals}

The energy drink used in this work was the red bull. It was purchased from the local markets in Mosul, Iraq as a form of $250 \mathrm{ml}$ cans.

\section{Animals}

Thirty adult male albino rats weighing $240 \pm 20 \mathrm{mg}$ and aging 4-5 months were obtained from the animal's house, college of veterinary medicine, University of Mosul. Rats were kept in the experimental room under suitable circumstances. Acclimatization of rats was for one week before proceeding the experiment and they were on free access to standard diet and water.

\section{Experimental design}

Rats were assigned to 3 groups, 10 animals for each and as follows, group one served as control group, on standard diet and water. Group two treated at dose of $10 \mathrm{ml} / \mathrm{kg} / \mathrm{rat}$ of red bull (This volume is equivalent to 3 cans of red bull consumed by adult human weighing 70-75 kg). Group three treated at dose of $20 \mathrm{ml} / \mathrm{kg} /$ rat of red bull. The beverage was given daily through oral route via intragastric gavage to all animals of group 2 and 3 for 30 days (10). After completing the experimental period each animal was sacrificed by decapitation.

\section{Histological evaluation}

Kidney and pancreas were excised and the specimens were fixed in the buffered neutral formalin (10\%) for more than 24 hours. Tissue processing were accomplished using standard methods and the tissue sections were stained using Mayer's hematoxylin and eosin and were observed by light microscope.

\section{Results}

\section{Kidney}

The histological structure of kidney sections in control group appeared to be normal without any histopathological changes (Figure 1). In group 2 renal sections revealed vacuolar degeneration of renal tubular epithelium, vascular congestion in the glomeruli as well as in the interstitial space and coagulative necrosis of renal tubular epithelium (Figure 2 and 3), additionally, atrophic glomeruli with widened urinary space and degenerative changes of renal tubular epithelium were also noticed (Figure 4). In group 3 there were more atrophic glomeruli, massive coagulative necrosis of renal tubular epithelium (Figure 5), furthermore, markedly dilated and congested blood vessels in the interstitial space and degenerative changes of the renal tubular epithelium were observed (Figure 6).

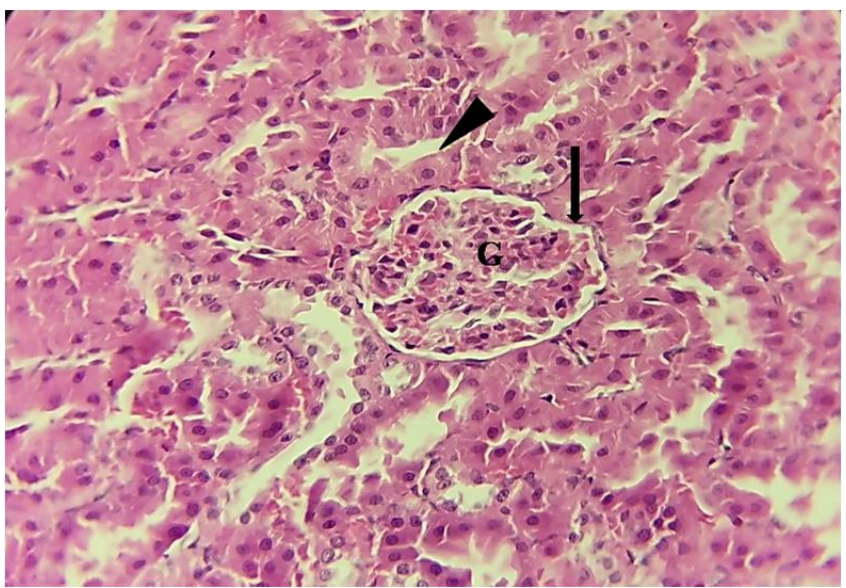

Figure 1: Renal tissue section of group 1 (control) revealing normal glomerulus $(G)$ with the surrounding urinary space (arrow) and normal proximal convoluted tubules (arrowhead). (H\&E X 400).

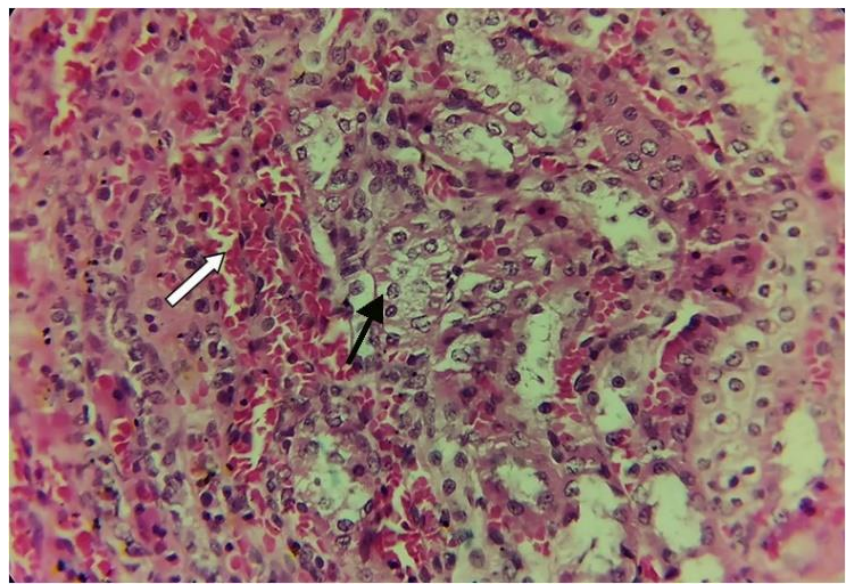

Figure 2: Renal tissue section of group 2 revealing vascular congestion in the interstitial space (white arrow) and vacuolar degeneration of renal tubular epithelium (black arrow). (H\&E X 400).

\section{Pancreas}

Normal pancreatic tissue sections were seen in rats of control group (Figure 7). The pancreatic tissue of group 2 showed vascular congestion of the islets of Langerhans, an increase in the size of the islets and necrosis of Langerhans cells (Figure 8). In rats of group 3, the pathological changes which recognized were, reduction in the size of the islets of Langerhans, vacuolation and degeneration of their cells (Figure 9), in addition to necrosis of other islets with mononuclear inflammatory cells infiltration (Figure 10). The pancreatic acini were seen to have degenerative changes (Figure 11). 


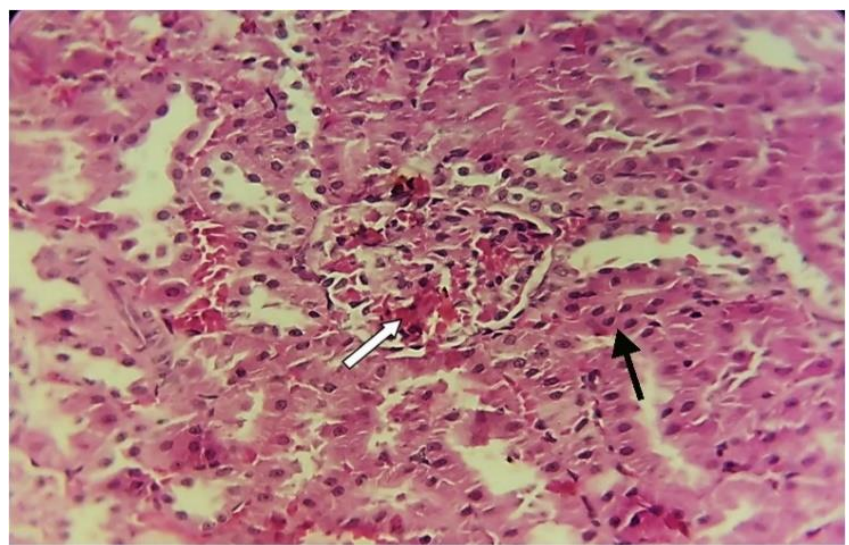

Figure 3: Renal tissue section of group 2 revealing vascular congestion in the glomerulus (white arrow) and coagulative necrosis of renal tubular epithelium (black arrow). (H\&E X 400).

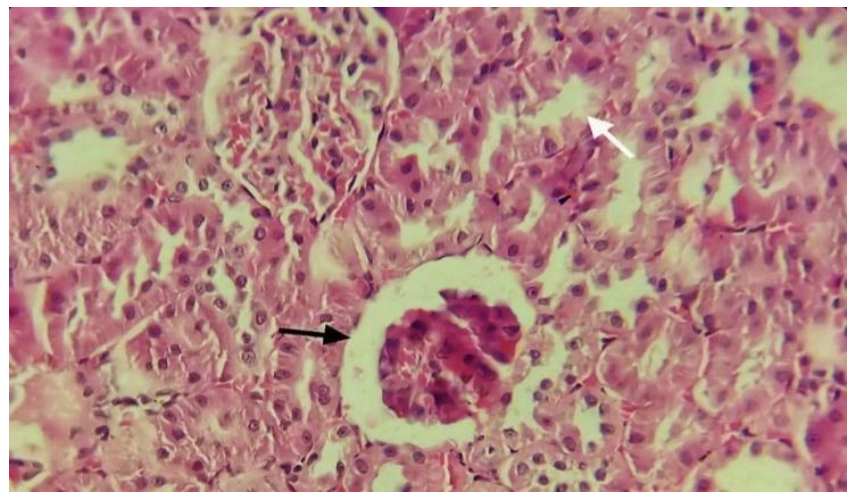

Figure 4: Renal tissue section of group 2 revealing atrophic glomeruli with widening of the urinary space (black arrow) and degenerative changes of renal tubular epithelium (white arrow). (H\&E X 400).

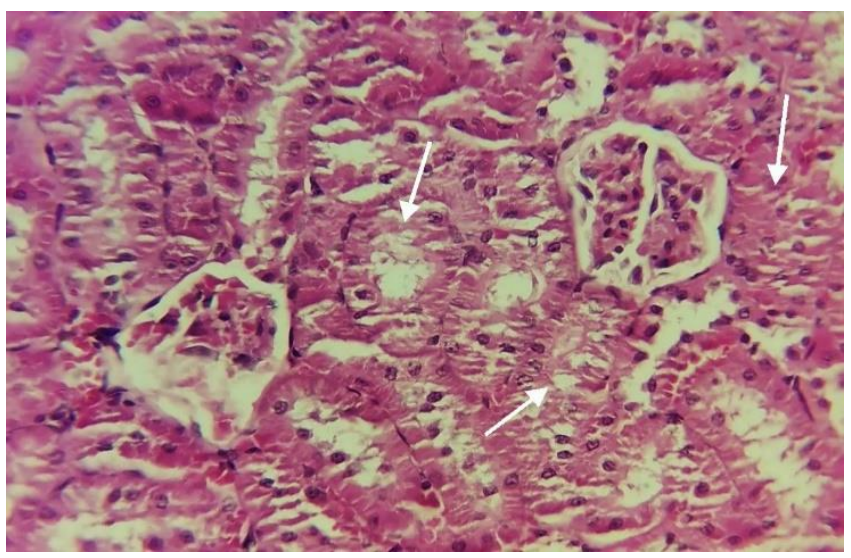

Figure 5: Renal tissue section of group 3 revealing massive coagulative necrosis of renal tubular epithelium (white arrows). (H\&E X 400).

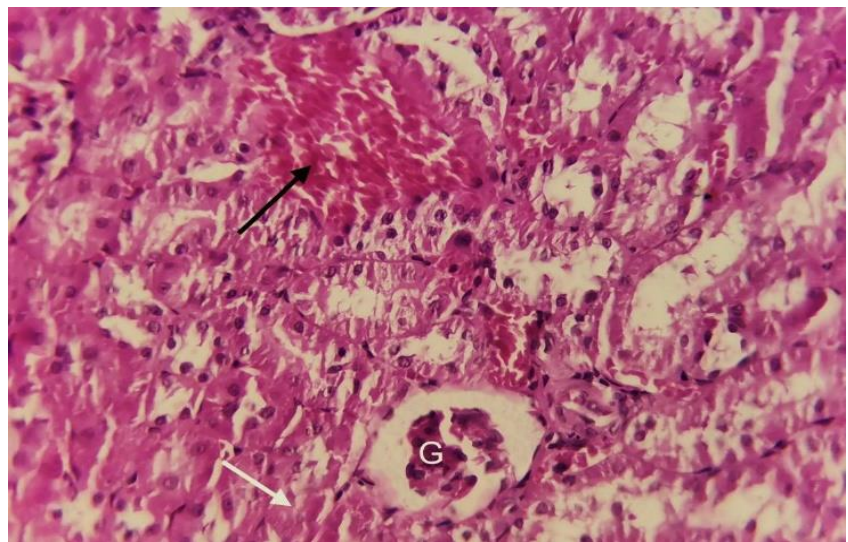

Figure 6: Renal tissue section of group 3 revealing marked vascular dilatation and congestion in the interstitial space (black arrow), degeneration of the renal tubular epithelium (white arrow) and atrophic glomeruli (G). (H\&E X 400).

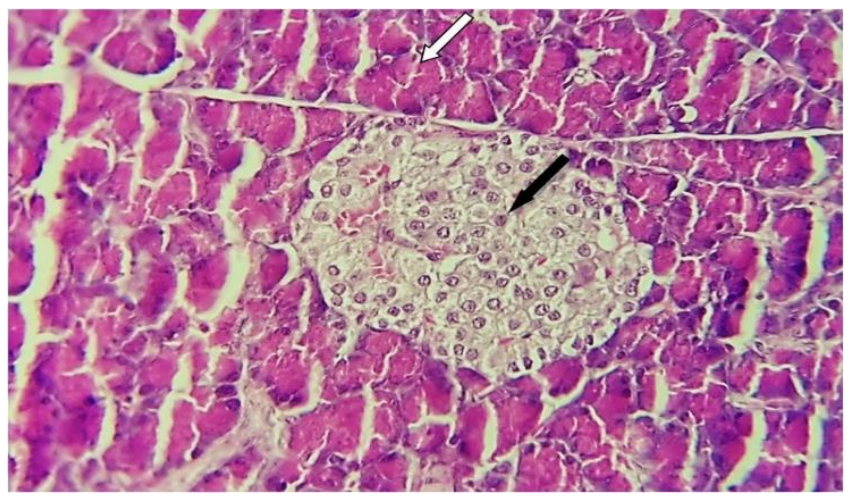

Figure 7: Pancreatic tissue section of group 1 (control group) this image revealing normal islets of Langerhans (black arrow) and pancreatic acini (white arrow). (H\&E X 400).

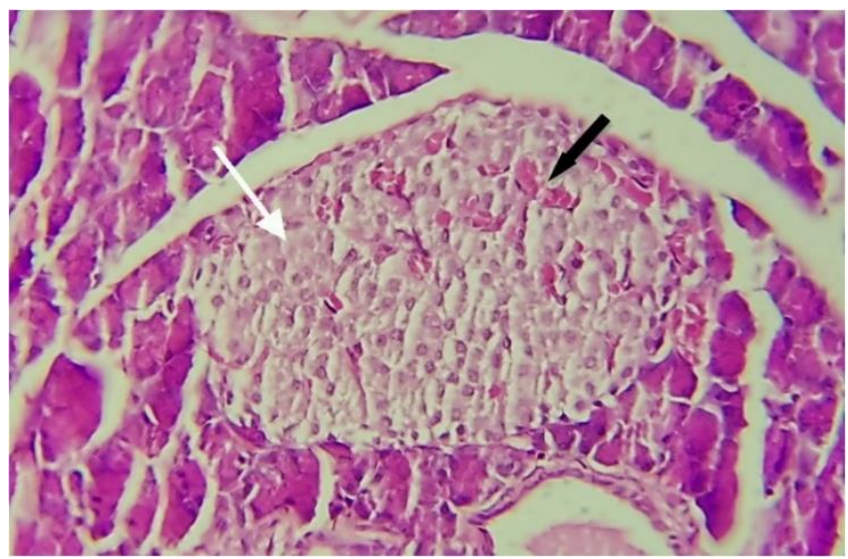

Figure 8: Pancreatic tissue section of group 2 revealing vascular congestion and increase in size (black arrow) and necrosis of Langerhans cells (white arrow). (H\&E X 400). 


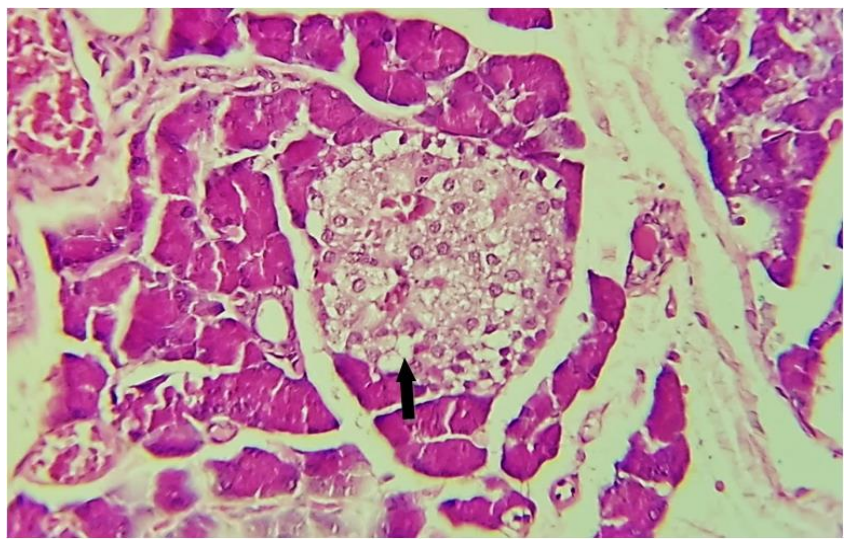

Figure 9: Pancreatic tissue section of group 3 revealing reduction in the size of the islets of Langerhans, in addition to vacuolation and degeneration of their cells (black arrow). (H\&E X 400).

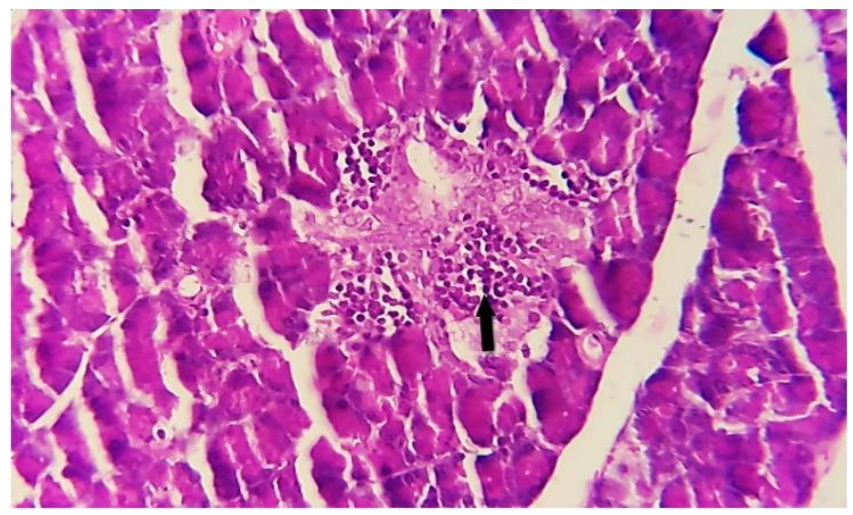

Figure 10: Pancreatic tissue section of group 3 revealing necrosis of the islets of Langerhans with mononuclear inflammatory cells infiltration (black arrow). (H\&E X 400).

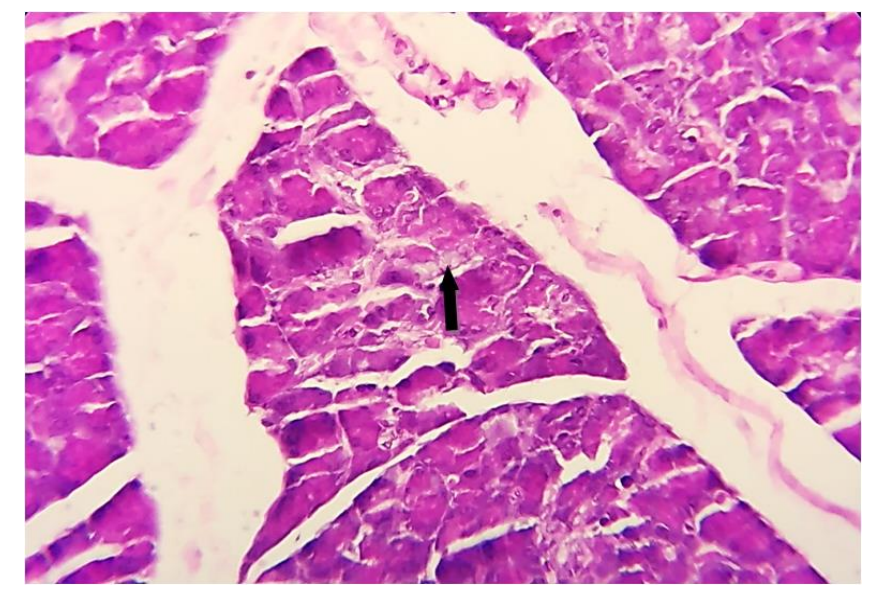

Figure 11: Pancreatic tissue section of group 3 revealing degeneration of pancreatic acini (black arrow). (H\&E X 400).

\section{Discussion}

In concurrence with the increasing ingestion of energy drinks in the last years, several researches were accomplished showing, as well as, explaining their toxic effects on different organs of the body (11). In the present experimental study daily oral administration of $10 \mathrm{ml} / \mathrm{kg} /$ day /rat of red bull for 30 days resulted in renal damage represented by vacuolar degeneration and coagulative necrosis of renal tubular epithelium, vascular congestion of glomeruli and in the interstitial spaces, besides atrophy of glomeruli. With increasing the dose to $20 \mathrm{ml} / \mathrm{kg}$ the histological changes in the kidney sections became so obvious and severe, there were more atrophic glomeruli, massive cogaulative necrosis of renal tubular epithelium, marked congestion and dilatation of the blood vessels and degeneration of renal tubular epithelium. The current findings are similar to the findings of the experimental studies of Mansy et al. (12), Salih et al. (13), and Ali (14), they found that giving low dose of energy drink leads to mild to moderate renal damage, whereas, high doses result in severe damage. Moreover, in human, cases of kidney injuries were reported following the consumption of these drinks $(15,16)$. Thus it is indicated that energy drinks are nephrotoxic on chronic consumption and their toxicity is a dose dependent.

The exact mechanism of renal damage is unknown. The ingredients of energy drinks are blamed to be the cause. Red bull is composed of caffeine, glucoronolactone, taurine, niacin, vitamins B2, B6, B12, pantothenic acid, inositol, carbonated water, sucrose, glucose, citric acid, flavors and caramel (17). Ali (14) concluded that caffeine alone or in combination with taurine or sugar are the reason of kidney damage following long term consumption of red bull. Caffeine elevates blood pressure thereafter increasing the blood pressure of afferent arterioles of glomerular tuft with subsequent glomerular damage (18). Also caffeine as suggested by Khayyat et al. (4) inhibits A2A adenosine receptors leading to elevation of creatinine, urea, as well as, uric acid and this will produce interstitial inflammation and renal damage.

Ekakitie et al. (19) observed that red bull affects the oxidative enzymes, likewise Mansy et al. (12) noticed a decreased level of antioxidant enzymes in the blood when red bull was given in high doses to rats leading to increase in reactive oxygen species and oxidative stress. Oxidative stress will cause degeneration and desquamation in renal tissue $(12,20,21)$. Although many case reports of acute pancreatitis have been recorded in association with energy drinks consumption, it is not $100 \%$ confirmed that these beverages are the reason of pancreatitis $(6,22)$. Therefore, till now experimental studies are carried out to observe and clarify the impact of various energy drinks ingestion on the pancreas (23). 
In the present study vascular congestion of the islets of Langerhans, an increase in the size of the islets and necrosis of Langerhans cells were associated with the administration of $10 \mathrm{ml} / \mathrm{kg}$ of red bull to rats of group 2 for 30 days. The changes in the pancreatic sections were more remarkable when the dose of red bull increased to $20 \mathrm{ml} / \mathrm{kg}$, there will be degeneration of the cells of pancreatic acini and those of islets of Langerhans, in addition to reduction in the size, as well as, necrosis of other islets with mononuclear inflammatory cells infiltration. These findings in the pancreatic tissue were also noticed by other investigators following treatment of rats with different doses of energy drinks for 4 weeks $(24,25)$. On the basis of this work with the mentioned literature, it can be stated that energy drinks when consumed for prolonged time can cause damage to the pancreas, and this damage is increased with increasing the dose of consumption.

Sadowska (26) and El Desouky et al. (27) mentioned that high concentration of sugar besides niacin in the energy drink may alter carbohydrate metabolism following their intake leading to increscent in the level of glucose and insulin in the blood accompanied by insulin resistance. This may explain the reason of the enlarged size of islets following consumption of low dose of red bull as a compensatory mechanism to reduce the high level of blood sugar by secreting more insulin. Increasing the dose and period of ingestion of energy drink will cause a further elevation in blood glucose level that may increase the production of reactive oxygen species precipitating oxidative stress and pancreatic tissue damage (24).

Also oxidative stress may occur owing to hyperglycemia (28). Hyperglycemia results from caffeine intake, the caffeine reduces the sensitivity of tissues toward insulin, impairs metabolism of glucose, and stimulates stress hormones release (as adrenaline) $(26,29)$. Oxidative stress in turn will cause insulin resistance, dysfunction and destruction of ßeta cells of pancreas (30).

\section{Conclusion}

It is concluded that administration of red bull to rats for 30 days will affect the histological structure of kidney as well as pancreas and this effect is a dose dependent. So attention and alertness is very important when this beverage is consumed for prolonged periods. Further researches are recommended in order to evaluate the effects of prolonged use of energy drinks on other body organs and to discover the exact mechanism of their effect in order to find the preventive measures in future.

\section{Acknowledgements}

We would like to express our deepest appreciation to College of Medicine, University of Mosul for supporting this work. Our thanks to the staff members of Animal house in College of Veterinary Medicine, University of Mosul for their help to accomplish this study.

\section{Ethical approval}

The research was approved by the Medical Research Ethics Committee, College of Medicine, University of Mosul.

\section{Conflict of interest}

There is no conflict of interest as declared by the authors.

\section{References}

1. Vercammen KA, Koma JW, Bleich SN. Trends in energy drink consumption among US adolescents and adults, 2003-2016. Am J Prev Med. 2019;56(6):827-833. DOI: 10.1016/j.amepre.2018.12.007

2. Higgins JP, Tuttle TD, Higgin CL. Energy beverages: contents and saftey. Mago Clin Proc. 2010;85:1033-1041. DOI: 10.4065/mcp. 2010.0381

3. Geith IM. Clinical pathology of caffeinated and non-caffeinated energy drinks: Review. Life Sci J. 2017;14(9): 21-36. DOI: $10.7537 / \mathrm{mars} 1 \mathrm{sj} 140917.03$

4. Khayyat L, Essawy A, Sorour J, Al Rawi M. Impact of some energy drinks on the structure and function of the kidney in wistar albino rats. Life Sci J. 2014;11(10):1131-1138. DOI: 10.7537/marslsj111014.170

5. Olaleru F, Odeigah P. Effects of energy drink on sperm morphology, haematological parameters and behavior of adult male mice. Annual Research \& Review in Biology. 2015;6(5):288-296. DOI: 10.9734/ARRB/2015/13573

6. Uwaifo GI. Beware Energy Drinks: A case of a toxic triad syndrome in a diabetic patient with nonalcoholic fatty liver disease. Am J Med Sci. 2019;358(4):304-311. DOI: 10.1016/j.amjms.2019.07.015

7. Adjene J, Emojevwe V, Idiapho D. Effects of long term consumption of energy drinks on the body and brain weights of adult wistar rats. J Exp Clin Anat. 2014;13(1):17-20. DOI: 10.4103/1596-2393.142925

8. Curran CP, Marczinski CA. Taurine, caffeine, and energy drinks: reviewing the risks to the adolescent brain. Birth Defects Res. 2017;109:1640-1648. DOI: $10.1002 / b d r 2.1177$

9. Wee JH, Min C, Park MW, Park I, Park B, Choi HG . Energy-drink consumption is associated with asthma, allergic rhinitis, and atopic dermatitis in Korean adolescents. Eur J Clin Nutr. 2020. In Press DOI: 10.1038/s41430-020-00812-2

10. Al-Khafaf AI, Ismail HKh, Al-Saidya AM. Histopathological effects of experimental exposure to lead on nervous system in albino female rats. Iraqi J Vet Sci. 2021;35(1):45-48. DOI: 10.33899/ijvs.2019.126248.1273

11. Piccioni A, Covino M, Zanza C, Longhitano Y, Tullo G, Bonadia N, Rinninella E, Ojetti V, Gasbarrini A, Franceschi F. Energy drinks: a narrative review of their physiological and pathological effects. Intern Med J. 2020; Epub ahead of print.Wiley Online Library: DOI: 10.1111/imj.14881

12. Mansy W, Alogaiel DM, Hanafi M, Zakaria E. Effects of chronic consumption of energy drinks on liver and kidney of experimental rats. Trop J pharm Res. 2017;16(12):2849-2856. DOI: 10.4314/tjpr.v16i12.8

13. Salih NA, Abdul-Sadaand IH, Abdulrahman NR. Histopathological effect of energy drink (red bull) on brain, liver, kidney and heart in rabbits. Med J Babylon. 2018;15:16-20. DOI: 10.4103/MJBL.MJBL_5_18

14. Ali LQ. Histological and physiological studies on the long-term effect of different concentrations of energy drink (tiger) on the renal and 
hepatic systems of young mice. Baghdad Sci J. 2019;16(4):816-823. DOI: $10.21123 / \mathrm{bsj} .2019 .16 .4 .0816$

15. Greene E, Oman K, Lefler M. Energy drink-induced acute kidney injury. Ann Pharmacother. 2014;48(10):1366-1370. DOI: $\underline{10.1177 / 1060028014541997}$

16. Al Yacoub R, Luczkiewicz D, christopher K. Acute kidney injury and hepatitis associated with energy drink consumption: case report. J Med Case Rep. 2020;14:23-26. DOI: 10.1186/s13256-019-2340-0

17. Laquale KM. Red bull: the other energy drink and its effect on performance. Human Kinetics. ATT. 2007; 12(2): 43-45. DOI: 10.1123/att.12.2.43

18. Riza M, Rutri AA. The comparison effect of energy drinks and coffee on creatinine level in rats. IJHHS. 2019;3(4):231-234. DOI: 10.31344/ijhhs.v3i4.107

19. Ekakitie L, Asagba SO, Orororo OC. Changes in tissue oxidative enzymes in rats exposed to red bull energy drink and alcohol. J Appl Sci Environ Manage. 2019;23(6):1175-1179. DOI: 10.4314/jasem.v23i6.27

20. Ahmed MA, Tayawi HM, Ibraheem MK. Protective effect of Silymarin against kidney injury induced by carbon tetrachloride in male rats. Iraqi $\mathbf{J}$ Vet Sci. 2019;33(1):127-130. DOI: 10.33899/ijvs.2019.125529.1051

21. Alabdaly YZ, Saeed MG, Al-hashemi HM. Effect of methotrexate and aspirin interaction and its relationship to oxidative stress in rats. Iraqi $\mathbf{J}$ Vet Sci. 2021;35(1):151-156. DOI: 10.33899/ijvs.2020.126490.1335

22. Shmelev A, Abdo A, Sachdev S, Shah U, Kowdley GC, Cunningham SC. Energetic etiologies of acute pancreatitis: a report of five cases. World J Gastrointes Pathophysiol. 2015;6(4):243-248. DOI: 10.4291/wjgp.v6.i4.243

23. Rehman F, Ul-Islam Z, Ul-Haq S, Faisal L, Rehman S, Kumar S. Morphometric study on the energy drink induced pancreatitis on wistar albino rats. J Dow Univ Health Sci. 2020;14(3):102-106. DOI: 10.36570/jduhs.2020.3.984

24. Ayoub N, ElBeshbeishy R. Impact of an energy drink on the structure of stomach and pancreas of albino rats: can omega- 3 provide a protection? PloS ONE. 2016;11(2):e0149191. DOI: 10.1371/journal.pone.0149191

25. Haroun H, Mohamed E, El Shahat AER, Labib H, Atef M. Adverse effects of energy drink on rat pancreas and the therapeutic role of each of bone marrow mesenchymal stem cells and Nigella Satira oil. Folia Morphol. 2020;79(2):272-279. DOI: 10.5603/FM.a2019.0069

26. Sadowska J. Evaluation of the effect of consuming an energy drink on the concentration of glucose and triacylglycerols and on fatty tissue deposition. A model study. Acta Sci Pol Technol Alimen. 2012;11(3):311-318. [Available at]

27. El Desouky AA, AboZaid A, El Saify GH, Noya DA. Ameliorative effect of omega-3 on energy drinks-induced pancreatic toxicity in adult male albino rats. EJH. 2019;42(2):324-333. DOI: 10.21608/ejh.2019.6526.1050

28. Ismail $\mathrm{HKh}$. Histopathological alterations of male and female reproductive systems induced by allaxon in rats. Iraqi J Vet Sci. 20xx. In Press. DOI: 10.33899/ijvs.2020.126626.1351

29. Gonzalez R, Mateos RM, Lechuga M, Gonzalez JJ, Corrales M, Rojas JA, Segundo C, Schwarz M. Synergic effects of sugar and caffeine on insulin mediated metabolomic alterations after an acute consumption of soft drinks. Electophoresis. 2017;38(18):2313-2322. DOI: 10.1002/elps.201700044

30. Robertson PR. Oxidative stress and impaired insulin secretion in type 2 diabetes. Curr Opin Pharmacol. 2006;6(6):615-619. DOI: 10.1016/j.coph.2006.09.002

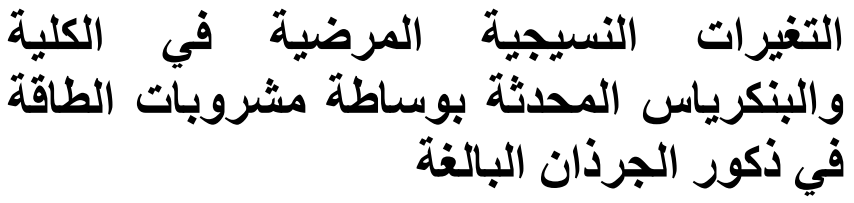

احمد هشام قاسم، مها عبد الجبار السماك و أشرف عبد الرحيم أيوب

فرع التشريح والأنسجة والأجنة، كلية الطب، جامعة الموصل،

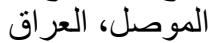

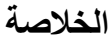

الدراسة تهدف إلى تقييم تأثير الجرع المختلفة لمشروب الريد بول

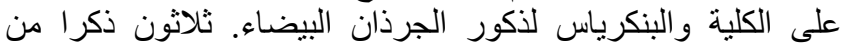

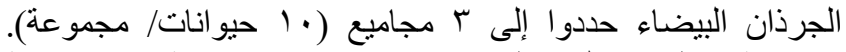

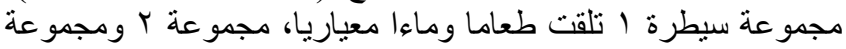

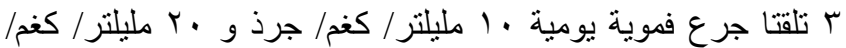

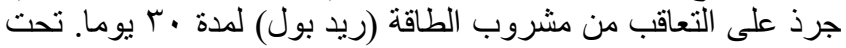

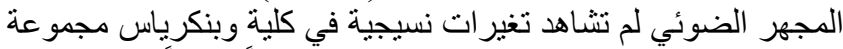

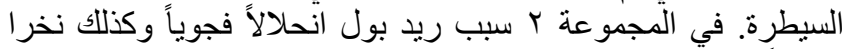

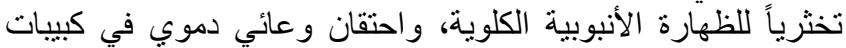

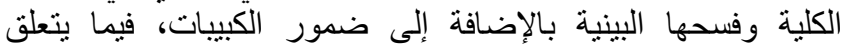

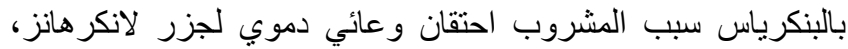

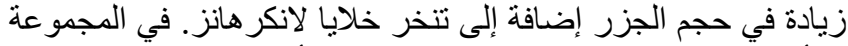

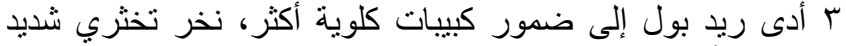

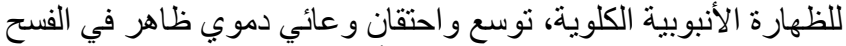

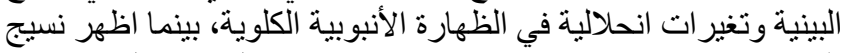

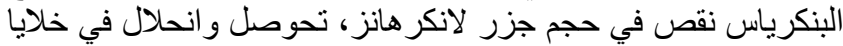

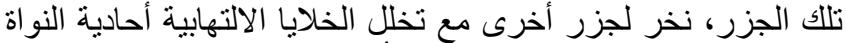

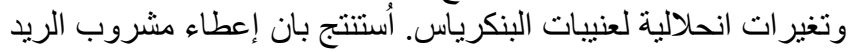

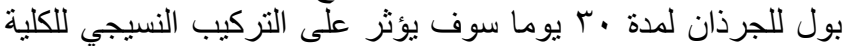
و البنكرياس و هذا التأثثر يعتمد على الجرعة. ئرة 